\title{
2006-1966: NAIT OR ABET? HOW DIFFERENT IS DIFFERENT?
}

\section{Rasha Morsi, Norfolk State University}

RASHA MORSI is an Assistant professor in the Department of Engineering at Norfolk State University. She has a B.Eng. degree from King's College, University of London (1991), an M.E. in Computer Engineering (1996), and a Ph.D. in Electrical and Computer Engineering (2002) from Old Dominion University. Her research interests include Digital Cellular Mobile Communication Networks and Protocols, Object Oriented Modeling and Simulation, and Technology Based Engineering Education.

\section{Wael Ibrahim, ECPI College of Technology}

Wael Ibrahim, is the Associate Dean for Computer Electronics Technology at ECPI College of Technology. Dr. Ibrahim has over thirteen years experience in education at the university level. He has an extensive experience in curriculum development for in-seat and online environments. His research interests are geared towards three main categories which are basic understanding of physical phenomena, engineering applications and engineering education enhancement. 


\title{
NAIT or ABET? How Different is Different?
}

\begin{abstract}
The main objective of Accreditation Board for Engineering and Technology (ABET) is to improve the overall quality of engineering education. This can be done through improving communication skills, encouraging team work, and providing an environment that allows the student to acquire the knowledge they need through technology as well as traditional methods. Acquiring ABET accreditation requires great commitment from faculty, staff, and school administration alike. A large number of Universities and colleges nationwide have made the commitment to acquire ABET as the accreditation body for their degrees. Over 70 Universities/colleges nationwide are accredited by the National Association of Industrial Technology (NAIT).
\end{abstract}

This paper compares the NAIT and ABET accreditation curriculum requirements for Computer Technology degrees and provides insight into possible strategies and the issues involved when trying to acquire ABET accreditation if you are currently NAIT accredited. Going from NAIT to ABET here becomes an even more difficult task simply because a number of courses that are required by NAIT for accreditation are not required by ABET. There lies a dilemma of going for ABET and possibly losing the NAIT accreditation in the process. A sample NAIT compliant curriculum is presented and the transition to an ABET compliant curriculum is achieved.

\section{Introduction}

Colleges and Universities nationwide seek accreditation for their Engineering, Engineering Technology, and Technology programs. Accreditation is a form of assurance that a program meets established quality standards. ABET is the most famous accreditation body in the United States for Engineering and Engineering Technology Programs. ABET now accredits Computer Science programs with the recent integration of the Computing Sciences Accreditation Board (CSAB) and its accreditation within ABET. "The Computing Accreditation Commission (CAC) is now well established and is effectively operating in the tradition of the Computer Science Accreditation Commission (CSAC).”[1]

\footnotetext{
ABET

Engineers Council for Professional Development (ECPD) was established in 1932 "to fill the apparent need for a joint program for upbuilding engineering as a profession."[2]. In 1980, ECPD was renamed the Accreditation Board for Engineering and Technology (ABET). ABET, Inc. is now the recognized accreditation organization for college and university programs. ABET accredits programs in applied science, computing, engineering, and technology. It is "among the
} 
most respected accreditation organizations in the U.S., ABET has provided leadership and quality assurance in higher education for over 70 years. ABET currently accredits some 2,700 programs at over 550 colleges and universities nationwide. Over 1,500 dedicated volunteers participate annually in ABET activities." [2]

Technology Accreditation Commission (TAC) of ABET accredits programs at associate's and bachelor's levels. Their accreditation criteria document states requirements for accreditation. Example program names are shown below:

- Aeronautical Engineering Technology

- Computer Engineering Technology

- Construction Engineering Technology

- Drafting/Design Engineering Technology (Mechanical)

- Electrical/Electronic(s) Engineering Technology

- Environmental Engineering Technology

- Industrial Engineering Technology

- Information Engineering Technology

- Manufacturing Engineering Technology

- Surveying/Geomatics Engineering Technology

- Telecommunications Engineering Technology

\section{NAIT}

The National Association of Industrial Technology [3] was founded in 1967. NAIT is an Industrial Technology accreditation organization that provides colleges and universities with the recognition of their attainment of specific professional goals and standards for Industrial Technology. This is the primary purpose of NAIT. The secondary purpose is to encourage other colleges and universities to strive toward these same professional goals and standards. NAIT accreditation ensures that the Institutions have "met a series of standards to provide industry with highly competent employees and assures the graduate of a NAIT accredited program that they are receiving a marketable degree through relevant curricula." [4]

Industrial Technology is stressed by NAIT, a detailed definition of which is provided in their 2003 accreditation handbook:

"Industrial Technology is a field of study designed to prepare technical and/or technical management-oriented professionals for employment in business, industry, education, and government. Industrial Technology degree programs and professionals in Industrial Technology careers typically will be involved with the:

a. Application of theories, concepts, and principles found in the humanities and the social and behavioral sciences, including a thorough grounding in communication skills. 
b. Understanding of the theories and the ability to apply the principles and concepts of mathematics and science and the application of computer fundamentals.

c. Application of concepts derived from, and current skills developed in, a variety of technical and related disciplines which may include, but are not limited to, materials and production processes, industrial management and human relations, marketing, communications, electronics, and graphics.

d. Completion of a field of specialization, for example, electronic data processing, computer aided design, computer integrated manufacturing, manufacturing, construction, energy, polymers, printing, safety, or transportation" [5]

NAIT is currently the accreditation body for Industrial Technology and related programs in a total of 76 institutions nationwide. NAIT "accredits a total of 104 Baccalaureate level programs (122 program/options) in 51 institutions and a total of 138 Associate level programs (184 program/options) in 28 institutions." [3]

The program name requirements are put in place by NAIT and they provide examples of program names that are acceptable in their accreditation manual and they include [5]:

- Manufacturing/Production Technology

- Communications Technology

- Computer Aided Design Technology

- Electronics Technology

- Computer Technology

- Packaging Technology

- Construction Technology

- Computer Integrated Manufacturing Technology

- Industrial Distribution Technology

- Aerospace Technology

Program names that include Engineering or Education and that imply an emphasis on either are rejected by NAIT. Section 5.3 in the NAIT powerpoint presentation available on NAIT's website states that for Major Programs, "Each major program and/or program option shall have appropriate titles (titles such as business, engineering, or education that imply the focus of the program is in a related field of study are not appropriate). (Associate and Baccalaureate)"[6]

\section{Requirements of NAIT and ABET}

Among other requirements, NAIT and ABET both stipulate minimum curriculum requirements for the Bachelors and Associates degrees. 


\section{- Curriculum requirements}

Figures 1 and 2 below show the curriculum requirements of both ABET and NAIT for the bachelor degrees. As can be seen in figure 2, NAIT requires between 12 and 24 hours of management courses. The list of the types of courses that can be covered in each category is shown in Table 1 [5].

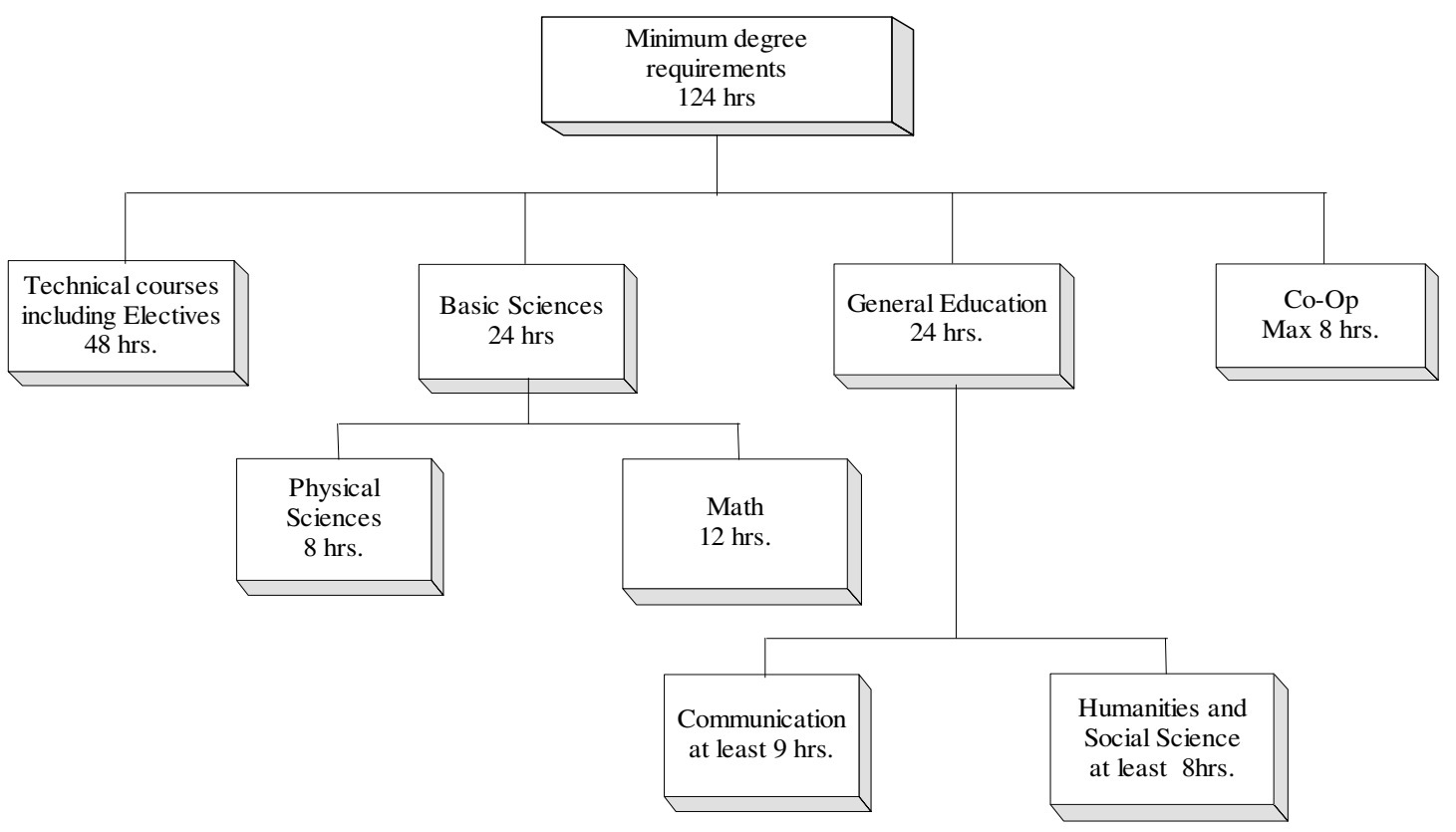

Figure 1. ABET Requirements for Engineering Technology Programs (BS)

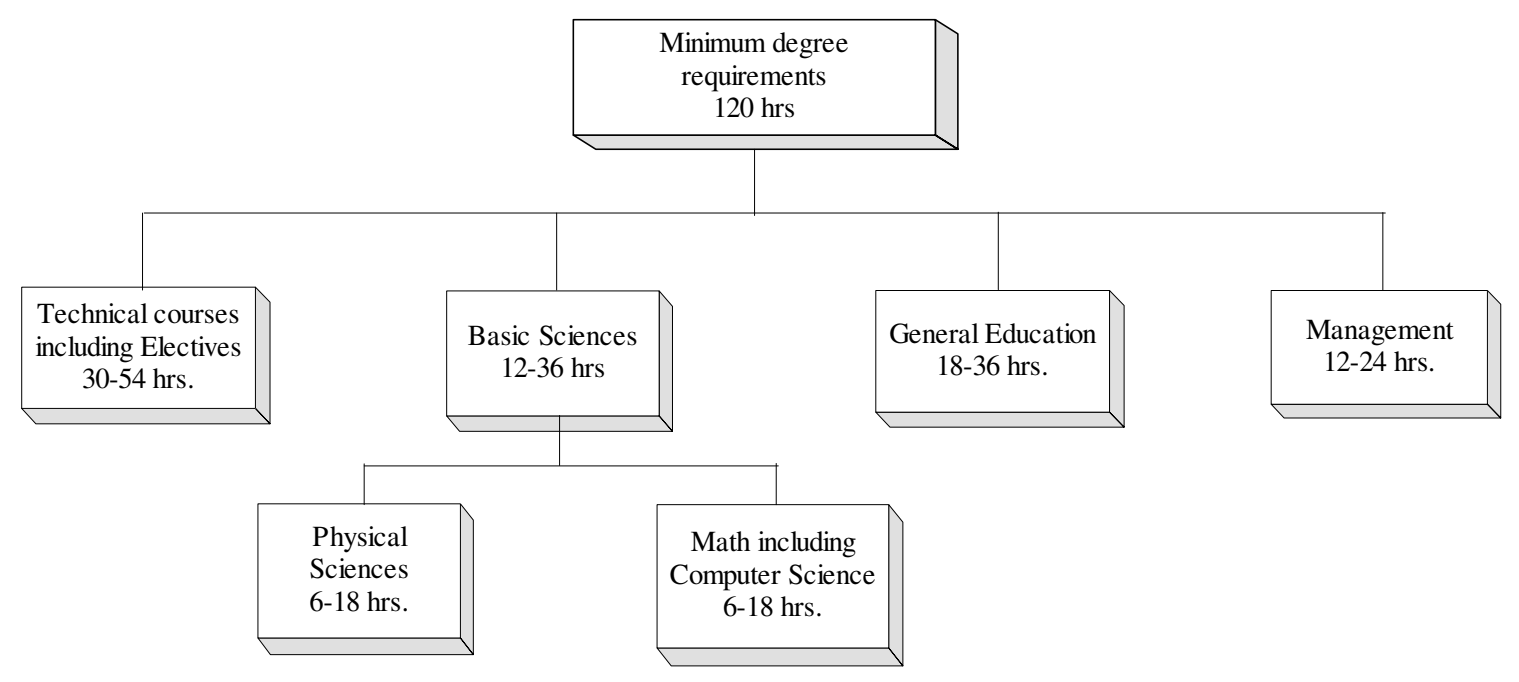

Figure 2. NAIT Requirements for Technology Programs (BS) 
Table 1. NAIT Major Programs: Minimum - Maximum Foundation Requirements [3]

\begin{tabular}{|c|c|}
\hline Content Categories & $\begin{array}{l}\text { Semester } \\
\text { Hours }\end{array}$ \\
\hline $\begin{array}{l}\text { General Education - Humanities, English, History, Economics, Sociology, Psychology, } \\
\text { Speech, etc. }\end{array}$ & $18-36$ \\
\hline $\begin{array}{l}\text { Mathematics - Algebra, Trigonometry, Analytical Geometry, Calculus, Statistics, } \\
\text { Computer Science, etc. }\end{array}$ & $6-18$ \\
\hline Physical Sciences - Physics, Chemistry, etc. & $6-18$ \\
\hline $\begin{array}{l}\text { Management - Total Quality Management, Quality Control, Production Planning and } \\
\text { Control, Industrial Supervision, Industrial Finance and Accounting, Industrial Safety } \\
\text { Management, Facilities Layout and Materials Handling, Industrial Ergonomics and Time } \\
\text { Study, Industrial Communications, Business Law, Marketing, Leadership, Project } \\
\text { Management, International Business, and Teaming, etc. }\end{array}$ & $12-24$ \\
\hline $\begin{array}{l}\text { Technical - Computer Integrated Manufacturing, Computer Aided Design, Electronics, } \\
\text { Materials Testing, Computer Technology, Packaging, Construction, Manufacturing } \\
\text { Processes, etc. }\end{array}$ & 24-36 \\
\hline Electives & $6-18$ \\
\hline
\end{tabular}

As can be seen from Figure 1, the requirements of ABET and NAIT are not too different except for the management requirement stipulated by NAIT. Duff [8] states that "analyses of the Engineering Criteria 2000 outcomes assessment process has appeared in the proceedings of several recent ASEE annual meetings (McGourty, 1999; Besterfield-Sacre, 2000) as well as in the pages of The Journal of Engineering Education (Felder, 2003) and in no case is the TACABET process at odds with NAIT accreditation standards". This is a promising statement for those who are currently seeking ABET if they were already NAIT accredited in degree programs like Electronics and Computer Technology.

Programs accredited by NAIT would, however, require to reduce/eliminate the management portion of the curriculum and increase the minimum requirements of Math, basic sciences and technical courses. In the following section, we will be covering possible methods to transition from NAIT to ABET.

\section{NAIT to ABET: a theoretical example}

35 Universities are NAIT accredited in some form of electronics/computer technology fields for both associate and baccalaureate degrees. Of these 35 universities, only fifteen are accredited in Computer and computer related Technology degree programs for both BS and AS degreed. 7 universities are accredited for BS degrees in Computer and computer related Technology degree programs. Table 2 below shows current accreditation status for the bachelor degrees in Computer/Computer related Technology degrees. 
Table 2. Baccalaureate Programs Accredited by NAIT

\begin{tabular}{|c|c|c|c|}
\hline & Institute & Degree & Accredited \\
\hline 1 & Bowling Green State University & Electronic \& Computer Technology & $\begin{array}{l}\text { Baccalaureate } \\
2004-2010\end{array}$ \\
\hline 2 & Central Missouri State University & $\begin{array}{c}\text { Electronics Technology-Computer } \\
\text { Electronics Technology }\end{array}$ & $\begin{array}{l}\text { Baccalaureate } \\
2000-2007\end{array}$ \\
\hline 3 & Elizabeth City State University & $\begin{array}{l}\text { Industrial Technology-Computer \& } \\
\text { Electronics Technology }\end{array}$ & $\begin{array}{c}\text { Baccalaureate } \\
\text { 2003-2009 }\end{array}$ \\
\hline 4 & Indiana State University & $\begin{array}{c}\text { Computer Technology, Computer } \\
\text { hardware Technology }\end{array}$ & $\begin{array}{l}\text { Baccalaureate } \\
2004-2010\end{array}$ \\
\hline 5 & Jackson State University & $\begin{array}{c}\text { Industrial Technology-Computer } \\
\text { Technology }\end{array}$ & $\begin{array}{c}\text { Baccalaureate } \\
2000-2006\end{array}$ \\
\hline 6 & Norfolk State University & $\begin{array}{c}\text { Computer Technology/Electronics } \\
\text { Technology }\end{array}$ & $\begin{array}{c}\text { Baccalaureate } \\
(2003-2009 \\
\end{array}$ \\
\hline 7 & San Jose State University & Industrial Technology & $\begin{array}{c}\text { Baccalaureate } \\
2003-2009\end{array}$ \\
\hline
\end{tabular}

Table 3. Curriculum requirements for NAIT accredited Baccalaureate programs

\begin{tabular}{|c|c|c|c|c|c|c|c|c|}
\hline & Institute & $\begin{array}{l}\text { Gen. } \\
\text { Ed }\end{array}$ & Math & $\begin{array}{l}\text { Phys. } \\
\text { Sci. }\end{array}$ & Management & Tech. & Elect. & $\begin{array}{l}\text { Total } \\
\text { Min }\end{array}$ \\
\hline 1 & $\begin{array}{l}\text { Bowling Green } \\
\text { State University }\end{array}$ & 24 & $10 / 11$ & 10 & 12 & 45 & 3 & 125 \\
\hline 2 & $\begin{array}{l}\text { Central } \\
\text { Missouri State } \\
\text { University }\end{array}$ & 34 & 9 & 8 & 9 & 35 & 26 & 121 \\
\hline 3 & $\begin{array}{c}\text { Elizabeth City } \\
\text { State University }\end{array}$ & 44 & 6 & 12 & 12 & 42 & 6 & 126 \\
\hline 4 & $\begin{array}{c}\text { Jackson State } \\
\text { University }\end{array}$ & & & & & & & 132 \\
\hline 5 & $\begin{array}{c}\text { Norfolk State } \\
\text { University }\end{array}$ & 40 & 10 & 8 & 12 & 56 & 6 & 120 \\
\hline 6 & $\begin{array}{c}\text { San Jose State } \\
\text { University }\end{array}$ & 30 & & & 15 & 59 & & \\
\hline & $\begin{array}{c}\text { RANGE } \\
\text { (Cr. Hrs.) }\end{array}$ & $24-44$ & $6-11$ & $8-12$ & $9-15$ & $35-59$ & $6-26$ & $120-132$ \\
\hline & AVERAGE & 34 & 9 & 10 & 12 & 48 & 10 & 123 \\
\hline
\end{tabular}

A survey was conducted of the 7 universities used as our resource for current NAIT accredited curricula. The information was available on the corresponding universities' websites. Some data was found to be unavailable.

Table 3 shows the range of requirements that have been deemed acceptable for accreditation by NAIT. Normally, the general education hours are more a requirement by the university and are hard to deviate from.

ABET requires that graduates of an Electronics/Computer Engineering Technology program have the following experiences: 


\begin{tabular}{|c||c|}
\hline \multicolumn{1}{|c|}{ Math } & Algebra, Trig. And Integral \& Differential Calculus \\
\hline $\begin{array}{c}\text { Physical and Natural } \\
\text { Sciences }\end{array}$ & $\begin{array}{l}\text { Physics, Chemistry or Life \& Earth Science + Labs } \\
\text { (where students conduct experiments, make } \\
\text { observations, measurements and documentation) }\end{array}$ \\
\hline $\begin{array}{c}\text { Social Science \& } \\
\text { Humanities }\end{array}$ & $\begin{array}{l}\text { Diversity and global \& societal impacts of } \\
\text { Technology }\end{array}$ \\
\hline \begin{tabular}{|l|l|}
\hline Technical Content \\
\hline Co-op
\end{tabular} & $\begin{array}{l}\text { Minimum of 124 credit hours for the degree, } 48 \\
\text { hours for the technical portion which should be 1/3 } \\
\text { to 2/3 of the total credit. 24 credits should be for } \\
\text { basic sciences. }\end{array}$ \\
\hline \hline & $\begin{array}{l}\text { Requires some type of faculty feedback } \\
\text { Suggestions are Formal report of experience and } \\
\text { job function during Co-op and a presentation to } \\
\text { faculty and industry member }\end{array}$ \\
\hline
\end{tabular}

Some of the requirements of ABET are that the technical portion of the curriculum become increasingly complex and that labs make use of analytical \& measurement equipment. Technical Courses are to use standard design practices, tools, techniques \& computer Hardware and software while capstone courses should combine technical and non-technical aspects of the degree.

Looking at the above basic requirements of ABET, without yet investigating the credit hour issue, it seems that for the Math requirements, NAIT accredited programs would require the addition, if not yet present, of Integral \& Differential Calculus.

After reviewing some of the accredited ABET programs [2], the following were observed to be typical courses that need to be covered in the math and physical sciences categories. These are shown in Table 4.

Table 4. Typical courses covered in ABET accredited programs in Computer Engineering Technology

\begin{tabular}{|c|l|}
\hline \multicolumn{1}{|c|}{ Category } & \multicolumn{1}{|c|}{ Typical courses covered } \\
\hline Math & $\begin{array}{l}\text { College Algebra } \\
\text { Trig }\end{array}$ \\
& $\begin{array}{l}\text { Calculus I and II } \\
\end{array}$ \\
& Some go as far as Discrete Mathematics \\
\hline Phys. Sci & $\begin{array}{l}\text { Typically Chemistry, General/University } \\
\text { Physics I and II }\end{array}$ \\
\hline
\end{tabular}


Using Table 3, the average credit hour assignment for each category was used for our sample NAIT program. As can be seen in Table 5 below, the average based sample NAIT program falls well in the NAIT accreditation standards. It can also be seen that the credit hour requirements are not too far removed from what ABET required as their minimum standards.

Table 5. Average of requirements for a NAIT accredited BS program in Computer Technology

\begin{tabular}{|l|c|l|}
\hline \multicolumn{1}{|c|}{$\begin{array}{c}\text { NAIT } \\
\text { Requirements }\end{array}$} & $\begin{array}{c}\text { NAIT } \\
\text { Program } \\
\text { Sample }\end{array}$ & $\begin{array}{c}\text { ABET } \\
\text { Minimum } \\
\text { Requirements }\end{array}$ \\
\hline $\begin{array}{l}\text { General } \\
\text { Education } \\
\text { (18-36 hrs) }\end{array}$ & 34 & $\begin{array}{l}\text { General } \\
\text { Education } \\
\text { (24 hrs) }\end{array}$ \\
\hline $\begin{array}{l}\text { Mathematics } \\
\text { (6-18 hrs) }\end{array}$ & 9 & Basic Sciences \\
\hline $\begin{array}{l}\text { Physical } \\
\text { Sciences } \\
\text { (6-18 hrs) }\end{array}$ & 10 & (24 hrs) \\
\hline $\begin{array}{l}\text { Management } \\
\text { (12-24 hrs })\end{array}$ & 12 & N/A \\
\hline $\begin{array}{l}\text { Technical } \\
(24-36 \text { hrs })\end{array}$ & 48 & $\begin{array}{l}\text { Technical } \\
\text { (48 hrs) }\end{array}$ \\
\hline \begin{tabular}{l|c|} 
Electives \\
(6-18)
\end{tabular} & 10 & $\begin{array}{l}\text { Total min. 124 } \\
\text { hrs. }\end{array}$ \\
\hline $\begin{array}{l}\text { Total min. 120 } \\
\text { hrs }\end{array}$ & 123 \\
\hline
\end{tabular}

The place where one can see the most required transition is in the Mathematics and Physical Sciences category. In the sample program the requirements are 19 hours, yet for ABET the minimum is 24 hours. It seems for the reviewed curricula that the mathematics requirements need to go from 9 to at least 12 hours, to cover topics up to at least Calculus II. Physical Sciences need to have labs associated with it and if the management courses are eliminated, then there will remain some credit hours needed to be added to the technical portion of the curriculum. It is still important to remember that the technical portion cannot exceed $2 / 3$ of the total number of credit hours for the degree program. That is for a degree with a 124 credit hour requirement, the technical hours cannot exceed 82 . Table 6 shows the changed requirements to our sample program. 
Table 6. Revised NAIT sample program for straight transition and phased transition to BS program in Computer Engineering Technology

\begin{tabular}{|c|c|c|c|c|}
\hline $\begin{array}{c}\text { NAIT } \\
\text { Requirements }\end{array}$ & $\begin{array}{c}\text { NAIT } \\
\text { Program } \\
\text { Sample }\end{array}$ & $\begin{array}{l}\text { Revised } \\
\text { NAIT } \\
\text { Program } \\
\text { Sample }\end{array}$ & $\begin{array}{c}\text { Revised } \\
\text { NAIT } \\
\text { Program } \\
\text { Sample } \\
\text { (phased } \\
\text { approach) }\end{array}$ & $\begin{array}{c}\text { ABET } \\
\text { Minimum } \\
\text { Requirements }\end{array}$ \\
\hline $\begin{array}{l}\text { General } \\
\text { Education } \\
(18-36 \text { hrs })\end{array}$ & 34 & 34 & 34 & $\begin{array}{l}\text { General } \\
\text { Education } \\
(24 \mathrm{hrs})\end{array}$ \\
\hline $\begin{array}{l}\text { Mathematics } \\
\text { (6-18 hrs) }\end{array}$ & 9 & 12 & 12 & \multirow{2}{*}{$\begin{array}{l}\text { Basic Sciences } \\
(24 \mathrm{hrs})\end{array}$} \\
\hline $\begin{array}{l}\text { Physical } \\
\text { Sciences } \\
(6-18 \mathrm{hrs})\end{array}$ & 10 & 12 & 12 & \\
\hline $\begin{array}{l}\text { Management } \\
(12-24 \mathrm{hrs})\end{array}$ & 12 & 0 & 12 & N/A \\
\hline $\begin{array}{l}\text { Technical } \\
\text { (24-36 hrs) }\end{array}$ & 48 & 54 & 48 & \multirow[t]{2}{*}{$\begin{array}{l}\text { Technical } \\
\text { (48 hrs) }\end{array}$} \\
\hline $\begin{array}{l}\text { Electives } \\
(6-18)\end{array}$ & 10 & 12 & 6 & \\
\hline $\begin{array}{l}\text { Total min. } 120 \\
\text { hrs }\end{array}$ & 123 & 124 & 124 & $\begin{array}{l}\text { Total min. } 124 \\
\text { hrs. }\end{array}$ \\
\hline
\end{tabular}

For this example, if the University requirements for General Education hours are more than 34, the Technical portion of the revised version can be reduced to 48 credit hours - the minimum required. This number includes electives.

It is only natural to fear losing the NAIT accreditation if a program wishes to go to ABET especially that the ABET ample would not include the management portion required by NAIT. The possible solution here might be to approach the accreditation process in a two phase fashion. The first phase would be to increase the Math, and physical science requirements as shown in the "Revised NAIT Program Sample (phased approach)" column. This way the management requirement stays intact and as can be seen from the table, the rest of the requirements exceed the NAIT required minimum. As the ABET process matures for the particular department, the curriculum credit hour requirement could be phased into the "Revised NAIT Program Sample" and the program would be fulfilling the minimum requirements for ABET as it pertains to the curriculum portion. 


\section{Conclusion}

From our investigation, it seems that Duff's statement rings true. The changes that were made to our sample curriculum were not too drastic and are definitely changes that can be accommodated. NAIT as well as ABET require assessment based on program outcomes. Of course acquiring accreditation requires much more than just the curriculum alignment with the accreditation body you are seeking accreditation from. Some of these other categories that require attention include: faculty qualifications, facilities, and assessment. As far as curriculum is concerned, the flexibility exists that would allow the changes needed to go to ABET from NAIT to be realistically achievable.

\section{Bibliography}

[1] CSAB, Inc. President's Message http://www.csab.org/pdf/President_s\%20Message\%202002.pdf

[2] ABET, Inc. , http://www.abet.org

[3] National Association for Industrial Technology (NAIT), http://www.NAIT.org

[4] Ohio Northern University, Accreditation Announcement http://www.onu.edu/a+s/techno/newsletter/NAITaccreditation.pdf

[5] NAIT accreditation handbook, 2003, http://www.nait.org/accred/accreditationhandbook2003.html\#1.1

[6] NAIT Slideshow, http://www.nait.org/accred/naitslideshow.ppt

[7] ABET Technology evaluation criteria document, http://www.abet.org/Linked\%20DocumentsUPDATE/Criteria\%20and\%20PP/T001\%2006-07\%20TAC\%20Criteria\%2012-1905.pdf

[8] Outcomes Assessment across Multiple Accreditation Agencies, Dr. Jon M. Duff http://www.nait.org/jit/Articles/duff110804.pdf 